\title{
Characterization of a Novel Yeast Synthesizing Melanin-like Pigment
}

\author{
By PRANAB ROY,* KALPANA K. NAYAK AND \\ NARENDRA K. PANDEY \\ Hindustan Lever Research Centre, Andheri (East), Bombay 400 099, India
}

(Received 27 June 1989; revised 22 August 1989; accepted 18 September 1989)

\begin{abstract}
A laboratory yeast isolate identified as Exophiala jeanselmei synthesized melanin and showed polyphenol oxidase activity with dihydroxyphenylalanine (DOPA) and pyrogallol. Electrophoresis on native and denaturing gels, and activity staining with DOPA revealed two immunologically distinguishable bands of $M_{\mathrm{r}}$ about 100000 and 120000 , which could be separated by $\left(\mathrm{NH}_{4}\right)_{2} \mathrm{SO}_{4}$ fractionation. The enzyme isolated from this yeast gave optimal activity at higher $\mathrm{pH}(8 \cdot 5-10)$ and temperature $\left(37-40^{\circ} \mathrm{C}\right)$ than other known melaninsynthesizing activities.
\end{abstract}

\section{INTRODUCTION}

Melanin is synthesized by many bacteria, fungi, animals and plants (Lerch, 1981; Swan, 1974); however, to our knowledge, there is no report of its occurrence in yeast. In this paper, we report the isolation of a budding yeast which synthesizes melanin in different media, and describe the properties of the enzyme tyrosinase (polyphenol oxidase). Tyrosinase (EC 1.14.18.1), a key enzyme in the biosynthesis of melanin, catalyses at least three sequential reactions in the biosynthesis of dopaquinone (an intermediate in melanin synthesis) from tyrosine (Burnett, 1971; Korner \& Pawalek, 1982). The rest of the pathway in melanogenesis is thought to be autocatalytic (Swan, 1974). Recently, dopachrome oxidoreductase has been implicated in blocking the biosynthesis of melanin at an intermediate stage (Barber et al., 1984).

In the course of our experiments to transform Saccharomyces cerevisiae AH22 (leu his) with plasmid YEp13 (Broach et al., 1979; Nayak et al., 1988) carrying the tyrosinase gene, mel, from plasmid pIJ703 of Streptomyces lividans strain 3132 (Katz et al., 1983), we observed a few black colonies on a selection plate. Light and scanning electron microscopy suggested that the pigmented colonies were composed of a budding yeast. Preliminary characterization of the isolate showed that it had no relationship to the host $S$. cerevisiae AH22 strain and did not contain a YEp1 3 derivative. A ${ }^{32} \mathrm{P}$-labelled nick-translated mel gene probe from plasmid pIJ703 (Katz et al., 1983) did not hybridize to the chromosomal DNA of the isolate. The isolated yeast strain has been identified as Exophiala jeanselmei (Langer) by the Centraalbureau voor Schimmelcultures, Baarn, The Netherlands.

\section{METHODS}

Media. The yeast was grown aerobically on a gyratory shaker (200 r.p.m.) at $30^{\circ} \mathrm{C}$ in minimal medium (containing, $\mathrm{g}^{-1}$ : yeast nitrogen base, 1.7; ammonium sulphate, 5; glucose, 20; $\mathrm{pH}$ 6), Sabouraud's medium (containing, $\mathrm{g}^{-1}$ : peptone, 10 ; glucose, $40 ; \mathrm{pH}^{6}$ ) or YEPD medium (containing, $\mathrm{gl}^{-1}$ : yeast extract, 10 ; peptone, 20; dextrose, 20; $\mathrm{pH} \mathrm{6).}$

Cell extraction. Yeast cells were sonicated in a Branson sonicator at $80 \%$ duty cycle with three pulses of $1 \mathrm{~min}$ each at $0{ }^{\circ} \mathrm{C}$ in $10 \mathrm{~mm}$-Tris/ $\mathrm{HCl}$, pH 7.5 and $1 \mathrm{~mm}$-EDTA (TE buffer). The supernatant obtained by centrifugation at 10000 r.p.m. for $15 \mathrm{~min}$ was used as the source of enzyme. Alternatively, the yeast cells were treated with the

Abbreviations: DOPA, DL-dihydroxyphenylalanine; NEM, $N$-ethylmaleimide. 
enzymes driselase and $\beta$-glucuronidase as detailed previously (Nayak et al., 1986). The protoplasts obtained were washed with citrate/phosphate buffer, $\mathrm{pH} 5 \cdot 8$, containing $1 \mathrm{M}$-sorbitol and then lysed with $1 \%$ SDS in TE buffer at $37^{\circ} \mathrm{C}$ for $30 \mathrm{~min} .1 \mathrm{mM}$-PMSF and $2.5 \mathrm{mM}-N$-ethylmaleimide (NEM) as protease inhibitors were added during extraction.

Extracts prepared by either method were fractionated by $\left(\mathrm{NH}_{4}\right)_{2} \mathrm{SO}_{4}$ as follows. Precipitation with $\left(\mathrm{NH}_{4}\right)_{2} \mathrm{SO}_{4}$ at $0-30 \%$ saturation was done in ice, maintaining the $\mathrm{pH}$ at $7 \cdot 5$, followed by centrifugation at 10000 r.p.m. for $10 \mathrm{~min}$. The supernatant was saturated up to $60 \%$ with $\left(\mathrm{NH}_{4}\right)_{2} \mathrm{SO}_{4}$, following which, the remaining proteins were precipitated in the $60-90 \%\left(\mathrm{NH}_{4}\right)_{2} \mathrm{SO}_{4}$ fraction. The fractions were dissolved in a minimum volume and dialysed against TE buffer.

Enzyme assay. Tyrosinase in the crude extract was assayed at pH 8.5 in $0.1 \mathrm{M}$-Tris/glycine buffer. For the $\left(\mathrm{NH}_{4}\right)_{2} \mathrm{SO}_{4}$ fractions, optimum activities were obtained at $\mathrm{pH} 10 \mathrm{in} 0.1 \mathrm{M}$-bicarbonate buffer. The assay mixture contained $2 \mathrm{mg}$ DOPA and $10 \mu \mathrm{g}$ dialysed protein in $2.5 \mathrm{ml}$ volume. Incubation was done at $37^{\circ} \mathrm{C}$ for $1 \mathrm{~h}$. Activities were calculated from $\triangle A_{475}$ obtained with correction for auto-oxidation of DOPA and the absorption due to inherent colour of the yeast extract. One unit of enzyme catalyses the transformation of $1 \mu \mathrm{mol}$ of DOPA $\mathrm{min}^{-1}$ under the assay conditions. The molar absorption coefficient of oxidation products of DOPA at $475 \mathrm{~nm}$ is $3600 \mathrm{M}^{-1} \mathrm{~cm}^{-1}$.

Gel electrophoresis and activity staining. SDS or native PAGE of the crude and $\left(\mathrm{NH}_{4}\right)_{2} \mathrm{SO}_{4}$-fractionated cell extracts was done under standard conditions (Laemmli, 1970). The standard $M_{\mathrm{r}}$ markers were stained with Coomassie Brilliant Blue R250. The rest of the gel was immersed in DOPA solution $\left(0.8 \mathrm{mg} \mathrm{m}^{-1}\right)$ for $1-2 \mathrm{~h}$. When distinct tyrosinase bands could be seen, the reaction was stopped by adding a few drops of $\beta$-mercaptoethanol.

\section{RESULTS AND DISCUSSION}

The doubling times of the yeast in minimal and Sabouraud's media were 4.5 and $3.5 \mathrm{~h}$, respectively. The intracellular black pigment was produced in minimal and Sabouraud's media with no traces of production of ethanol (analysed by GLC on Porapak column at $85^{\circ} \mathrm{C}$ ). In YEPD medium the cells were cream-coloured rather than black and produced ethanol. Maximum growth and pigmentation occurred at $37-40^{\circ} \mathrm{C}$ both on agar plates and in liquid media. Varying the glucose or $\left(\mathrm{NH}_{4}\right)_{2} \mathrm{SO}_{4}$ concentration from 5 to $50 \mathrm{~g} \mathrm{l}^{-1}$ in minimal medium did not affect the growth and pigment production. There was no evidence of repression or the Crabtree effect (DeDeken, 1966). The pigment could be visualized after about $24 \mathrm{~h}$ incubation. In a typical shake culture experiment about $12 \mathrm{~g}$ glucose $1^{-1}$ was utilized in $48 \mathrm{~h}$ in minimal medium. The addition of $20 \mathrm{~g} \mathrm{l}^{-1}$ or more peptone to minimal medium drastically reduced melanogenesis without impairing growth. However, the addition of various amino acids, e.g. histidine, threonine, tyrosine, methionine, leucine, cysteine, proline or DOPA at $1 \mathrm{~mm}$ each did not affect pigmentation.

In order to characterize the pigment, the supernatant of sonicated cells was compared to the auto-oxidation product of DOPA, i.e. melanin. Both had identical UV and visible absorption spectra $(190-700 \mathrm{~nm})$. Most of the pigment remained in the cell pellet and, as expected of melanin, it could not be extracted with detergents such as SDS or Triton X-100 (used at $1 \%$ ) or solvents such as chloroform, ethanol, methanol and acetone. Treatment with $2 \mathrm{M}-\mathrm{NaOH}$ at $50{ }^{\circ} \mathrm{C}$ for $16 \mathrm{~h}$ resulted in partial solubilization $(40 \%, \mathrm{w} / \mathrm{w})$ of the pigment. The neutralized alkali extract of the pigment and the in vitro product of the tyrosinase had the same absorption and fluorescence spectra as the auto-oxidation product of DOPA.

The supernatant (crude extract) was used as the source of tyrosinase and assayed with DOPA and pyrogallol as substrates. Electrophoresis of the crude extract or dialysates of $\left(\mathrm{NH}_{4}\right)_{2} \mathrm{SO}_{4}$ fractions on $7.5 \%$ or $10 \%$ polyacrylamide gel containing SDS showed two discrete bands of approximate $M_{\mathrm{r}} 100000$ to 120000 when stained with DOPA $\left(0.8 \mathrm{mg} \mathrm{ml}^{-1}\right)$ for tyrosinase activity (Fig. $1 a, b$ ). This is analogous to the pattern of tyrosinases from mouse or human melanoma, though they have different molecular sizes. Saccharomyces cerevisiae did not show any activity-stainable band either by native or denaturing gel electrophoresis. It has been reported that in mouse and human melanoma, the tyrosinase can be post-translationally modified to various isoenzymic forms (Burnett, 1971 ; Lerch, 1981). The enzyme activity was lost if the extracts were boiled in Laemmli buffer (Laemmli, 1970) but remained unaffected by $1 \%$ SDS.

Precipitation of tyrosinase activity from the crude extract showed it to be distributed in the $0-30 \%, 30-60 \%$ and $60-90 \%$ saturated $\left(\mathrm{NH}_{4}\right)_{2} \mathrm{SO}_{4}$ fractions (Table 1). This could be due to the 


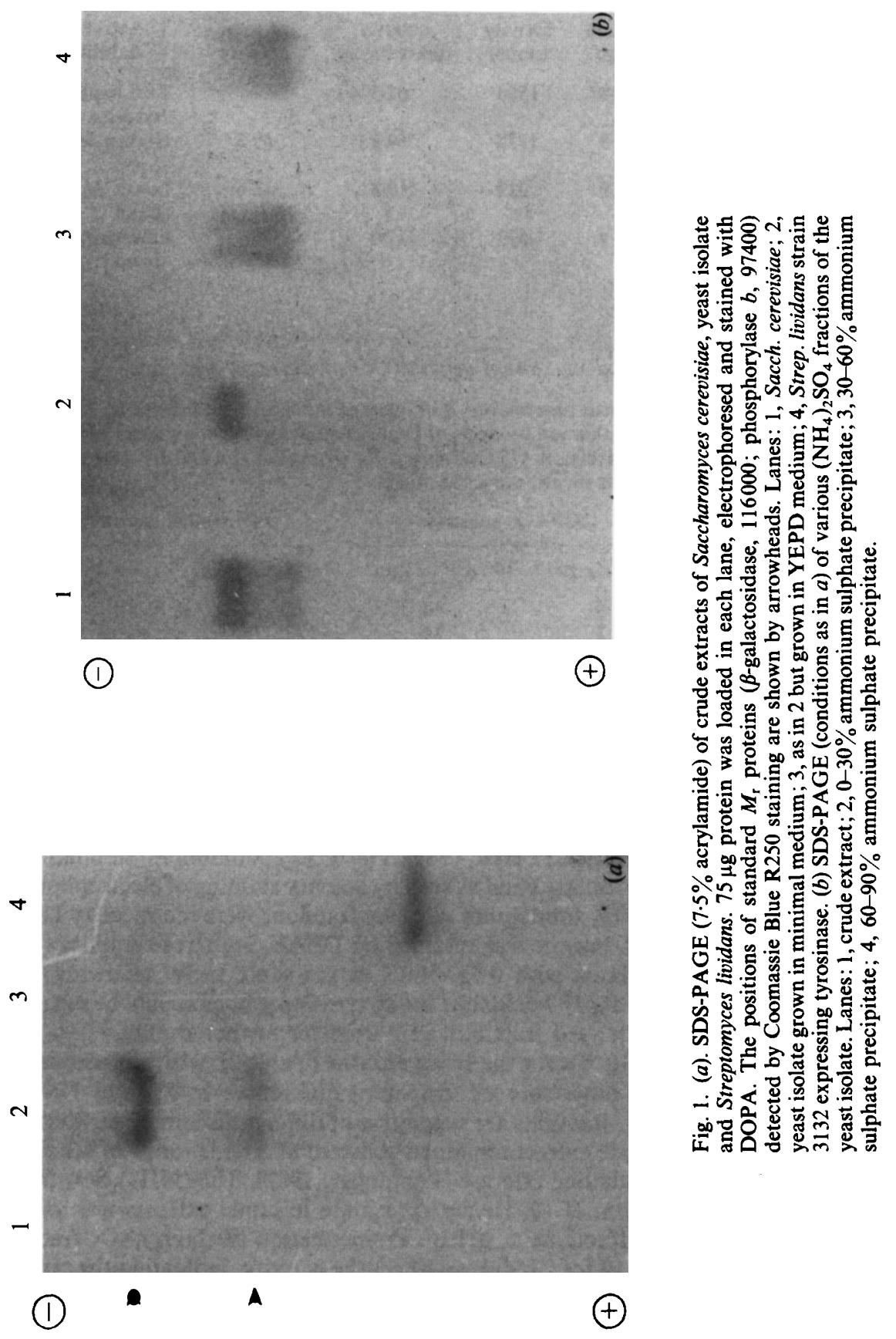


Table 1. Fractionation of tyrosinase activity in crude extract

Crude extract was assayed at $\mathrm{pH} 8.5$ and the $\left(\mathrm{NH}_{4}\right)_{2} \mathrm{SO}_{4}$ fractions at $\mathrm{pH} 10.0$, using $0.8 \mathrm{mg} \mathrm{DOPA} \mathrm{ml}^{-1}$ as substrate.

\begin{tabular}{|c|c|c|c|c|c|}
\hline Fraction & $\begin{array}{c}\text { Total } \\
\text { protein } \\
(\mathrm{mg})\end{array}$ & $\begin{array}{c}\text { Total } \\
\text { activity } \\
\text { (units) }\end{array}$ & $\begin{array}{c}\text { Specific } \\
\text { activity } \\
\text { (units } \mathrm{mg}^{-1} \text { ) }\end{array}$ & $\begin{array}{l}\text { Percentage } \\
\text { of total } \\
\text { activity }\end{array}$ & $\begin{array}{l}\text { Activity } \\
\text { staining }\end{array}$ \\
\hline Crude extract & 24.8 & 1550 & 62.5 & - & $\begin{array}{l}\text { Two bands of } \\
\text { tyrosinase }\end{array}$ \\
\hline $0-30 \%\left(\mathrm{NH}_{4}\right)_{2} \mathrm{SO}_{4}$ & 16.8 & 1170 & 69.6 & $59 \cdot 3$ & $\begin{array}{l}\text { Higher } M_{\mathrm{r}} \\
\text { band }\end{array}$ \\
\hline $30-60 \%\left(\mathrm{NH}_{4}\right)_{2} \mathrm{SO}_{4}$ & 1.9 & 227 & $119 \cdot 3$ & 11.6 & $\begin{array}{l}\text { Lower } M_{\mathrm{r}} \\
\text { band }\end{array}$ \\
\hline $60-90 \%\left(\mathrm{NH}_{4}\right)_{2} \mathrm{SO}_{4}$ & 4.9 & 573 & 117.0 & $29 \cdot 1$ & $\begin{array}{l}\text { Lower } M_{\mathrm{r}} \\
\text { band }\end{array}$ \\
\hline
\end{tabular}

Table 2. $K_{m}$ and maximum velocity ( $V$ ) of different fractions

$K_{m}$ and $V$ were calculated from Lineweaver-Burk plots of the respective substrates. Molar absorption coefficients for oxidation products of DOPA and pyrogallol were taken as 3600 and $2470 \mathrm{M}^{-1} \mathrm{~cm}^{-1}$, respectively, at $475 \mathrm{~nm}$. Assays for pyrogallol and DOPA were done under identical conditions as mentioned in Methods.

$\begin{array}{lcccc}\quad \text { Fraction } & \overbrace{10^{4} \times K_{\mathrm{m}}(\mathrm{M})} & 10^{6} \times V\left(\mathrm{M} \mathrm{min}^{-1}\right) & \overbrace{10^{4} \times K_{\mathrm{m}}(\mathrm{M})} & 10^{6} \times V\left(\mathrm{M} \mathrm{min}^{-1}\right) \\ \begin{array}{l}\text { Crude extract } \\ 0-30 \% \text { Ammonium } \\ \text { sulphate }\end{array} & 7.6 & 4.6 & 7 & 5 \\ \begin{array}{c}60-90 \% \text { Ammonium } \\ \text { sulphate }\end{array} & 5.3 & 7.6 & 25 & 19 \\ \end{array}$

multiple forms of tyrosinase, varying in charge, $M_{\mathrm{r}}$ or both, as found in mushroom and melanoma cells (Keevil \& Mason, 1978; Lerch, 1981). The 0-30\% ammonium sulphate fraction was enriched in the higher $M_{\mathrm{r}}$ tyrosinase band as seen by activity staining of electrophoresed gel (Fig. $1 b$ ). The $30-60 \%$ and $60-90 \%$ ammonium sulphate fractions were identical and enriched in the lower $M_{\mathrm{r}}$ band. The yeast enzyme was retained by DEAE-Sepharose equilibrated with $50 \mathrm{~mm}$-Tris/ $\mathrm{HCl}, \mathrm{pH} 7.5$, and eluted with $0.5 \mathrm{M}-\mathrm{NaCl}$ in the same buffer, showing that the protein has a net negative charge at $\mathrm{pH} 7 \cdot 5$. Since the two tyrosinase bands could be separated by $\left(\mathrm{NH}_{4}\right)_{2} \mathrm{SO}_{4}$ fractionation, the dialysed fractions were used for further studies.

The $K_{\mathrm{m}}$ for DOPA was $7.6 \times 10^{-4} \mathrm{M}$ for the crude enzyme (Table 2), which is comparable to $K_{\mathrm{m}}$ values for tyrosinases from other sources. Apparent differences in $K_{\mathrm{m}}$ and $V$ values of activities in different $\left(\mathrm{NH}_{4}\right)_{2} \mathrm{SO}_{4}$ fractions are suggestive of different isoenzymes. Surprisingly, the tyrosinase activity in the crude extract remained constant at a wide range of alkaline pHs (8.5 and above) as reported for choline esterase (Lehninger, 1982). The $\left(\mathrm{NH}_{4}\right)_{2} \mathrm{SO}_{4}$ fractions, however, exhibited a pH optimum of 10 . Hence, tyrosinase in crude extracts was assayed at $\mathrm{pH} 8.5$ and that in $\left(\mathrm{NH}_{4}\right)_{2} \mathrm{SO}_{4}$ fractions at $\mathrm{pH} 10$. Preincubation of $\left(\mathrm{NH}_{4}\right)_{2} \mathrm{SO}_{4}$ fractions in $0.05 \mathrm{M}$-bicarbonate buffer at $\mathrm{pH} 10$ for $2 \mathrm{~h}$ did not affect the activity, indicating the stability of the enzyme. At $\mathrm{pH} \mathrm{8.5}$, all the $\left(\mathrm{NH}_{4}\right)_{2} \mathrm{SO}_{4}$ fractions showed a characteristic lag in tyrosinase activity which was overcome if the assay was performed at pH 10 (Fig. 2). This is analogous to the case of human melanoma and skin tyrosinase (Tripathi et al., 1988) where there is a pHdependent lag period in the cresolase activity of the tyrosinase. An important difference is that the $\mathrm{pH}$ range for activity of human tyrosinase is from 5.3 to 6.8 whereas in the yeast tyrosinase it is from 8.5 to 10 . Under our assay conditions, enzyme activity was greatest at $37-40^{\circ} \mathrm{C}$, which is 


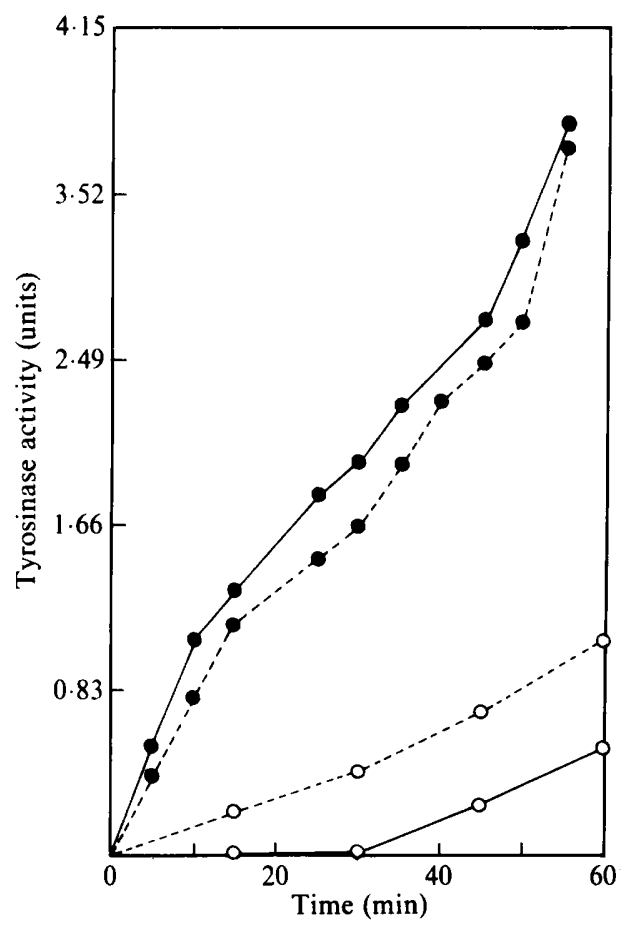

Fig. 2. Comparison of tyrosinase activity (as a function of time) of the $0-30 \%$ and $60-90 \%\left(\mathrm{NH}_{4}\right)_{2} \mathrm{SO}_{4}$ fractions at $\mathrm{pH} 8.5$ and $\mathrm{pH} 10$. The assays were carried out at a DOPA concentration of $2 \mathrm{mM}$, with $20 \mu \mathrm{g}$ enzyme protein. For assay at $\mathrm{pH} 8 \cdot 5,0.05 \mathrm{M}$-Tris/glycine buffer was used and for assay at $\mathrm{pH} 10$, $0.05 \mathrm{M}$-carbonate/bicarbonate buffer was used. The 30-60\% ammonium sulphate fraction behaved identically to the $60-90 \%$ ammonium sulphate fraction. $\left(\mathrm{NH}_{4}\right)_{2} \mathrm{SO}_{4}$ saturation and assay $\mathrm{pH}:-0$, $60-90 \%$ pH 10.0; - -, $0-30 \%$, pH 10.0; O- $, 60-90 \%, \mathrm{pH} 8.5 ; 0 \cdots \bigcirc, 0-30 \%, \mathrm{pH} 8.5$.

similar to the optimum temperature for growth and pigmentation. The exclusion of protease inhibitors (PMSF, NEM) from the extraction buffer did not alter the tyrosinase activity. Additionally, the enzyme activity was also not affected by mild treatment of the crude extract with chymotrypsin, pronase or proteinase $\mathrm{K}[12.5 \mu \mathrm{g} \text { protease (mg crude extract protein })^{-1}$ at $37^{\circ} \mathrm{C}$ for $1 \mathrm{~h}$ ]. However, incubation for $16 \mathrm{~h}$ with these proteases completely abolished the activity, as examined by activity staining on gels.

A polyclonal antibody raised against the higher $M_{\mathrm{r}}$ tyrosinase band obtained by electrophoretic elution from the SDS-PAGE was reacted with the extract. Various concentrations of crude extract proteins and antiserum were tested, and the antibody selectively neutralized the higher $M_{\mathrm{r}}$ protein. There was no cross-reaction with the lower $M_{\mathrm{r}}$ tyrosinase band (Fig. 3). The preimmune serum did not affect the activity of either band. Hence the antigenic determinants in the two polypeptides may be different. Native PAGE of the yeast extract also showed two distinct bands on activity staining.

Tyrosine with DOPA at $25: 1(\mathrm{w} / \mathrm{w})$ gave enzyme activity in the crude extract that was $16 \%$ of that obtained with DOPA alone as substrate. Pyrogallol was a good substrate for the enzyme whereas tyrosine, catechol, 4-isopropylcatechol, orcinol and phenol were poor substrates (concentrations used in the assay varied between $0.32 \mathrm{mM}$ to $4.0 \mathrm{~mm}$ in each case). Dopachrome oxidoreductase activity in the crude extract was found to be insignificant (Barber et al., 1984). Table 3 shows the effects of various additions to the assay buffer on the tyrosinase activity. Tyrosinases are known to be copper containing enzymes, with possible involvement of cysteine 
1

2

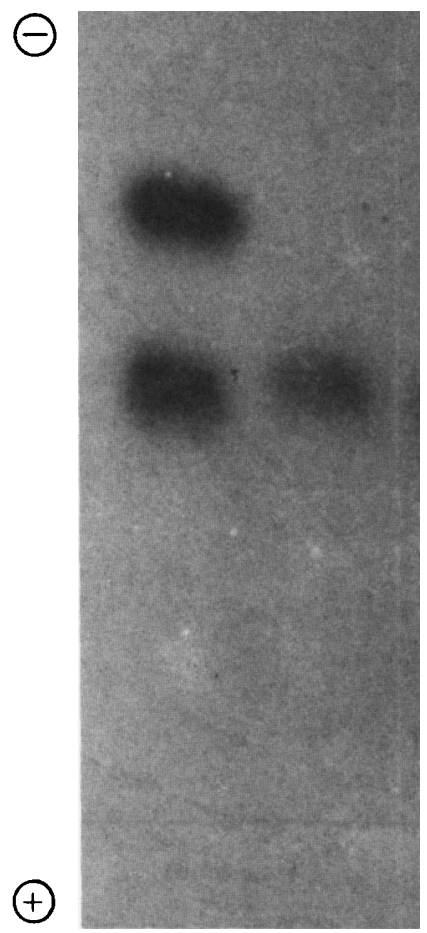

Fig. 3. $7 \cdot 5 \%$ acrylamide gel electrophoresis of crude extract of yeast isolate (1) crude extract (2) supernatant after treatment with anti-tyrosinase antibody raised against higher $\boldsymbol{M}_{\mathrm{r}}$ tyrosinase band. Activity staining of the gel was done with DOPA.

Table 3. In vitro assay for tyrosinase in the crude extract in presence of various compounds

The conditions of assay were as described in Methods. Dialysed crude extract $(80 \mu \mathrm{g})$ was used in each assay in $0.1 \mathrm{M}$-Tris/glycine buffer, $\mathrm{pH} 8.5$. The control, with no addition, had an activity of 1.8 units with respect to DOPA.

\section{Addition}

None

$\mathrm{CuSO}_{4}(1-10 \mu \mathrm{M})$

$\beta$-Mercaptoethanol or dithiothreitol (1 mM)

Dithiothreitol (1 mM)

Diethyldithiocarbamate (1 mM)

Bipyridyl (1 mM)

Sodium potassium tartrate $(1 \mathrm{mM})$

Cysteine. $\mathrm{HCl}(1-10 \mathrm{~mm})$

$N$-Ethylmaleimide $(2 \cdot 5 \mathrm{~mm})$

PMSF (1 mM)

Activity $(\%)$
100
100
0
0
10
100
100
0
100
100

and histidine at the active site (Lerch, 1978, 1981). The observation that NEM does not inhibit the tyrosinase activity indicates that thiol group(s) are not essential. Metal ion chelators like sodium potassium tartrate or bipyridyl may not be able to interact with the bound copper in the tyrosinase and hence do not inhibit the reaction as also reported for mouse melanoma tyrosinase (Barber et al., 1984). The inhibition by dithiothreitol or 2-mercaptoethanol may be due to inhibition of oxidation of DOPA rather than to modification of the enzyme. Diethyldithiocarbamate, a known inhibitor of tyrosinase of mouse melanoma (Barber et al., 1984) significantly inhibited the activity of yeast tyrosinase. 
The properties of the tyrosinase reported here show that it is a polyphenol oxidase (Keevil \& Mason, 1978). It is distinct from all reported tyrosinases in $M_{\mathrm{r}}$, and $\mathrm{pH}$ and temperature characteristics. The two activity-stainable bands seem to be distinct enzymes rather than subunits of the same enzyme.

The authors thank Professor D. A. Hopwood for the Streptomyces plasmid pIJ703 and Streptomyces lividans strain 3132, also Mr R. M. Pradhan for electron microscopy.

\section{REFERENCES}

Barber, J. H., Townsend, D., Olds, D. P. \& King, R. A. (1984). Dopachrome oxidoreductase: a new enzyme in the pigment pathway. Journal of Investigative Dermatology 83, 145-149.

BROACH, J. R., Strathern, J. N. \& Hicks, J. B. (1979). Transformation in yeast: development of a hybrid cloning vector and isolation of the $C A N 1$ gene. Gene 8, 121-123.

BURNETT, J. B. (1971). The tyrosinase of mouse melanoma. Isolation and molecular properties. Journal of Biological Chemistry 246, 3079-3089.

DeDekEN, R. H. (1966). The Crabtree effect: a regulatory system in yeast. Journal of General Microbiology 44, 149-156.

KATZ, E., ThOMPSON, J. C. \& Hopwood, D. A. (1983). Cloning and expression of the tyrosinase gene from Streptomyces antibioticus in Streptomyces lividans. Journal of General Microbiology 129, 2703-2714.

KeEvil, T. \& Mason, H. S. (1978). Molecular oxygen in biological oxidations - an overview. Methods in Enzymology 52, 3-40.

Korner, A. \& Pawalek, J. M. (1982). Mammalian tyrosinase catalyses three reactions in the biosynthesis of melanin. Science 217, 1163-1165.

LAEMMLI, U. K. (1970). Cleavage of structural proteins during the assembly of the head of bacteriophage T4. Nature, London 227, 680-685.

LEHNINGER, A. L. (1982). Enzymes: kinetics and inhibition. In Principles of Biochemistry, pp. 147-168. New York: Worth Publishers.

LERCH, K. (1978). Amino acid sequence of tyrosinase from Neurospora crassa. Proceedings of the National Academy of Sciences of the United States of America 75, 3635-3639.

LERCH, K. (1981). Copper monooxygenases: tyrosinases and dopamine beta monooxygenase. In Metal Ions in Biological Systems. pp. 143-186. Edited by $\mathrm{H}$. Sigel. New York: Marcel Dekker.

NAYAK, K. K., Padbidri, A., Hirlekar, M. G. \& PANDEY, N. K. (1986). Rapid method for preparation of protoplasts of Rhodotorula glutinis. Current Science 55, 926-927.

Nayak, K. K., Pandey, N. K. \& Roy, P. (1988). Cloning of tyrosinase gene from Streptomyces lividans in Escherichia coli. Indian Journal of Biochemistry and Biophysics 25, 515-517.

Swan, G. A. (1974). Structure, chemistry and biosynthesis of the melanins. In Progress in the Chemistry of Organic Natural Products, vol. 31, pp. 521-582. Edited by W. Herz, H. Grisebach \& G. W. Kirby. New York: Springer Verlag.

Tripathi, R. K., ChaAya Devi, C. \& Rumaiah, A. (1988). $\mathrm{pH}$ dependent interconversion of two forms of tyrosinase in human skin. Biochemical Journal 252, $481-487$. 